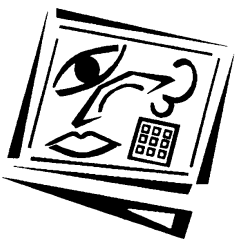

\title{
First year students' experiences with technology: Are they really digital natives?
}

\author{
Gregor E. Kennedy, Terry S. Judd, Anna Churchward, Kathleen Gray \\ The University of Melbourne
}

\section{Kerri-Lee Krause}

Griffith University

\begin{abstract}
This paper reports on a study conducted in 2006 with more than 2,000 incoming firstyear Australian university students. Students were asked about their access to, use of and preferences for an array of established and emerging technologies and technology based tools. The results show that many first year students are highly tech-savvy. However, when one moves beyond entrenched technologies and tools (e.g. computers, mobile phones, email), the patterns of access and use of a range of other technologies show considerable variation. The findings are discussed in light of Prensky's (2001a) notions of the 'Digital Natives' and the implications for using technology to support teaching and learning in higher education.
\end{abstract}

\section{Introduction}

In 2001 Marc Prensky published companion papers on a new generation of students: the 'Digital Natives'. The basic thrust of Prensky's argument was that this new group of students coming into universities was fundamentally different from any that educators had seen before. Digital Natives had "spent their entire lives surrounded by and using computers, videogames, digital music players, video cams, cell phones, and all the other toys and tools of the digital age" (Prensky, 2001a, p. 1). Prensky maintained that the digital culture and environment in which the Natives had grown up had changed the way they think: "It is now clear that as a result of this ubiquitous environment and the sheer volume of their interaction with it, today's students think and process information fundamentally differently from their predecessors." (p. 1). Furthermore, in what can only be regarded as a bold claim, Prensky suggested that "It is very likely that our students' brains have physically changed - and are different from ours - as a result of how they grew up." (p. 1). This paper takes the first of these claims as its starting point. While it does not address claims about fundamental differences in information processing or neuroplasticity, it does question the cultural and environmental assumptions underpinning the construct of the Digital Natives.

Since Prensky (2001a, 2001b) coined the term, a considerable amount of discussion in education circles has centred on the Digital Natives (also referred to as the 'Net Generation', the 'Y Generation' and 'Millennials'). The argument has changed little from that originally posed by Prensky: the digital culture in which the Digital Natives have grown up has influenced their preferences and skills in a number of key areas related to education (see Oblinger, 2003, 2006; Gros, 2003; Gibbons, 2007). Prensky's stance has also remained unaltered over this period; he states in a recent article "... our 
students are clamouring for these [new] technologies to be used as part of their education, in part because they are things that the students have already mastered and use in their daily lives, and in part because they realise just how useful they can be." (Prensky, 2007; p. 41). Digital Natives are said to prefer receiving information quickly; be adept at processing information rapidly; prefer multi-tasking and non-linear access to information; have a low tolerance for lectures; prefer active rather than passive learning, and rely heavily on communications technologies to access information and to carry out social and professional interactions (Prensky 2001a, 2001b; Oblinger, 2003; Gros, 2003; Frand, 2000).

Prensky (2001a) not only pointed to the supposed natural technological affinity and literacy of the Digital Natives, he also expressed concern at an apparent lack of technological literacy among educators. He labelled lecturers in higher education 'Digital Immigrants'; foreigners in the digital lands of the Net Generation, and regarded the disparity between the Natives and the Immigrants as the "the biggest single problem facing education today" (p. 2). The preferences and skills that characterise the Digital Natives were said to be incompatible with the current teaching practices of the Immigrants. Prensky and other commentators (Oblinger, 2003; Frand, 2000) suggest that because of this disparity educators need to adjust their pedagogical models to suit the new kind of learner they are encountering in this new generation of students. Not surprisingly, this argument has gained widespread attention in higher education circles (e.g. Doherty, 2005; Rodley, 2005).

However, the premises underpinning these arguments warrant closer examination before university educators set about overhauling established curricula and teaching and learning practices. These arguments are predicated on a general assumption that students coming into universities have had a comparatively universal and uniform digital upbringing. It is assumed that the technological experiences of students are more or less homogeneous and that most, if not all, incoming university students are Digital Natives. Not only is it assumed that these students will have had broadly universal experiences, but that they will also have a sophisticated knowledge and understanding of information and communication technologies (ICTs). Such generalisations risk overlooking a more complex mix of technology based skills, knowledge and preferences among the student population.

An evidence-based understanding of students' technological experiences is vital in informing higher education policy and practice. A thorough understanding of students' technological experiences will have clear implications for areas such as student access, equity, and transition. Institutional decision making associated with the management and administration of information and communications technologies technological infrastructure support, resource investment, student and staff support would also benefit from evidence about students' existing experiences with technology. Finally, an investigation of students' current technological experiences will have implications for ways in which technology could potentially be harnessed in pedagogically sound ways to improve teaching and learning.

\section{Background to this study}

Perhaps surprisingly, little empirical research has been published on students' general use of technology in the context of Australian higher education. We do know that teenagers and young adults in Australia are high owners and users of technology including computers, the Internet and mobile phones (NetRatings, 2005; Australian 
Psychological Society, 2004). For example, the Australian Bureau of Statistics reported that in 2003, 99\% of 12-14 year olds used a computer at home or at school and $88 \%$ accessed the Internet. In the context of higher education, Krause, Hartley, James and McInnes (2005) reported that first year students were spending 4.2 hours per week on the web for study and research and only 3\% said they never used the web for study purposes. In a more recent survey of first-year engineering and business students, Oliver and Goerke (2007) found that high proportions of students (over 90\%) used online resources for study purposes. They also noted a growth in students' general use of instant messaging, blogs and podcasting between 2005 and 2007. However, they also found that the majority of students rarely or never used these technologies for study.

More comprehensive research has been carried out in the American higher education context. In 2002 the Pew Internet and American Life Project documented the high proportion of U.S. students who were using the Internet for their studies (Jones \& Madden, 2002). This study was one of the first to document how high numbers of college students used the internet to access information and used web-based email and instant messaging to communicate both with staff and fellow students. More recently, Kvavik (2005) surveyed 4,374 freshman and senior college students and found they were frequent users of email, instant messaging, word processing and Internet browsing and this use varied by students' majors. High levels of use and skill did not necessarily translate into preferences for increased use of technology in the classroom. While $31 \%$ of students indicated that they would like 'extensive' use of technology in the classroom, $26 \%$ of students said they would prefer classes with 'limited' or 'no' technology. Two factors that impacted on students' preferences were previous positive experiences with technology in the classroom and previous use and skill with technology generally.

In a follow up to this study, Caruso and Kvavik (2005) present a broad and comprehensive report of the technological experiences of over 18,000 university students. It is difficult to do justice to the detailed findings of such a large study in a paper such as this, but it is clear from their research that ICT permeates all aspects of students' lives. However, they also found that students are comfortable with a core set of technologies but are less comfortable with specialised technologies. Replicating Kvavik's earlier findings (Kvavik, 2005), they again found that high levels of use and skill did not necessarily translate into preferences for increased use of technology in the classroom and that students prefer technology to a moderate degree and as a supplement in courses.

Within this context, the aims of our study were straightforward. The first was to empirically document the degree to which incoming first year students at a large Australian metropolitan university access and use an array of technologies and technology based tools. In addition to the more entrenched technologies that have typically been the focus of this type of investigation (e.g. basic computer skills, email), this study also focussed on how students use a range of more recent or emerging, technology based tools (including social networking, blogs, wikis, RSS, VoIP, and podcasting).

The second aim was to determine the degree to which students themselves report wanting to use particular technologies to support their studies at university. Finally, given an implicit assumption, often made in commentaries on the Digital Natives, that because students are using particular technologies in their everyday lives they want to 
use them in their studies, we sought to investigate this empirically with a small group of emerging technologies. The final aim, therefore, was to determine whether the extent to which students use technology in their everyday lives is related to their preferences for their use at university.

\section{Method}

\section{Sample}

Data were collected from first year students who were commencing their studies at The University of Melbourne in 2006. In total, 2120 students completed the questionnaire used in this study which represented $27.2 \%$ of first year students at the University. As we were interested in students who ascribe to the category of 'Digital Native' based on age, analyses for this study were restricted to students born after $1980(\mathrm{n}=1973 ; 25.3 \%$ of first year students).

Most of the students who participated in the study were born between 1985 and 1988 (accounting for $94.4 \%$ of the sample), meaning that they were aged between 17 and 21 when they completed the survey. Many more females than males responded to the survey ( $62.4 \%$ females; $37.5 \%$ males), approximately a third of the sample were from a non-English speaking background (34.9\% NESB; $64.8 \%$ ESB) and about a quarter of the sample were International students (23.4\% international; $75.2 \%$ local students). Data were collected from students in nine of the ten University faculties offering first year courses. The only Faculty not independently represented - the Faculty of Music - was nevertheless represented through a number of students undertaking combined degrees.

\section{Measure - questionnaire}

A four page questionnaire, developed specifically for this study, asked students about their access to, use of, skills with, and preferences for an array of established and emerging technologies and technology based tools. The questionnaire comprised four main sections: demographic information (11 items), access to hardware and the Internet (16 items), use of and skills with technology based tools (Computer: 10 items; Web: 22 items; Mobile phones: 7 items) and preferences for the use of technology based tools in University studies (34 items). Only a subset of items are reported in this paper due to space limitations.

\section{Procedure}

Data was collected during orientation week and the first week of Semester 1, 2006. Key staff from faculties across the University (e.g. Assistant Deans, Information Technology; Assistant Deans, Teaching and Learning; Faculty Managers) were invited to participate in the study. Once in principle agreement had been established, contact was made with staff who had responsibilities for teaching or administration in specific disciplines (e.g. dentistry, chemistry, education, psychology, economics, law, etc). Appropriate times to carry out data collection in student orientation or introductory sessions were negotiated with each discipline contact. A member of the research team and one or two research assistants attended a session and would firstly brief students about the project and inform them that participation was voluntary and confidential. Students who participated then completed the survey before returning it. Twenty such survey sessions were conducted across the University. 


\section{Results}

\section{Students' access to technology}

Students were asked about their access to a range of technology hardware (computers, mobile phones, memory sticks, digital cameras, etc) and their access to the Internet. Students who indicated that they had access "exclusively for my own use" or "any time I need it, though shared with other people" were combined into a single category ("unrestricted"). Similarly, students who indicated they were "Not Sure" and "Missing" data were combined into a single category. The results are presented in Table 1.

Table 1: The percentage of students who have 'unrestricted', 'limited' or 'no' access to hardware and the Internet.

\begin{tabular}{|c|c|c|c|c|c|}
\hline \multicolumn{2}{|c|}{ Hardware } & $\begin{array}{c}\text { Unrestricted } \\
\text { access }\end{array}$ & $\begin{array}{c}\text { Limited } \\
\text { access }\end{array}$ & $\begin{array}{c}\text { No } \\
\text { access }\end{array}$ & $\begin{array}{l}\text { Not sure } \\
\text { / missing }\end{array}$ \\
\hline \multicolumn{2}{|c|}{ Mobile phone } & 96.4 & 0.9 & 1.5 & 1.3 \\
\hline \multicolumn{2}{|c|}{ Desktop computer } & 89.5 & 4.9 & 3.7 & 1.9 \\
\hline \multicolumn{2}{|c|}{ Digital camera } & 76.0 & 8.9 & 13.7 & 1.4 \\
\hline \multicolumn{2}{|c|}{ Memory stick } & 72.5 & 7.1 & 17.3 & 3.1 \\
\hline \multicolumn{2}{|c|}{ MP3 player (iPod) } & 68.9 & 5.7 & 23.3 & 2.2 \\
\hline \multicolumn{2}{|c|}{ 'Laptop' computer } & 63.2 & 10.0 & 24.0 & 2.8 \\
\hline \multicolumn{2}{|c|}{ Games console } & 47.4 & 13.2 & 36.6 & 2.8 \\
\hline \multicolumn{2}{|c|}{ Electronic organiser (PDA) } & 10.8 & 7.8 & 77.3 & 4.1 \\
\hline \multirow{3}{*}{ Internet } & Broadband & 72.9 & 5.7 & 18.1 & 3.3 \\
\hline & Dialup & 44.1 & 6.1 & 44.0 & 5.7 \\
\hline & Wireless & 37.0 & 8.6 & 48.3 & 6.1 \\
\hline
\end{tabular}

Table 1 shows that most commonly a moderate to high proportion of students have unrestricted access to the hardware we asked about. As would be expected, a very high proportion of students have unrestricted access to a desktop computer $(89.5 \%)$. Additional analyses showed that $70.5 \%$ of students have access to both a desktop and a laptop computer while only $0.6 \%$ of students $(n=11)$ have access to neither. While unrestricted access to mobile phones is almost universal $(96.4 \%)$, the vast majority of students indicated they do not have access to PDAs $(77.3 \%)$. A relatively high proportion of students have unrestricted access to portable memory sticks $(72.5 \%)$ and MP3 players (68.9\%); however, these technologies are nowhere near ubiquitous with around one-fifth of the student body having no access to them. Finally, while almost half the sample had unrestricted access to a games console, over one third of respondents $(36.6 \%)$ had no access. With respect to Internet access, $72.9 \%$ of students reported having unrestricted access to a broadband connection (Table 1). Fewer than $14 \%$ of students still relied on dialup Internet access and only $1.4 \%$ of students reported having no Internet access at all.

Not surprisingly, Table 2 shows that most students are relying on computers for creating digital documents and for general study purposes. Many students are familiar with creating or editing digital images (only 16.0\% have not done this in the last year) and while students do not create multimedia presentations very frequently, they are clearly familiar with this activity (only $11.1 \%$ have not done this in the last year). Half the students in the sample had used a computer to create a web page, but perhaps surprisingly, half had never done this. A large proportion of students are using their computer to listen to music daily or weekly $(84.0 \%)$ and while there are clearly student 'gamers', $38.5 \%$ of students have not used a games console in the last year. 
Table 2: Percentages showing how often students use computer based technologies

\begin{tabular}{|l|c|c|c|c|c|}
\multicolumn{1}{|c}{ Computer } & \multicolumn{4}{c|}{ Percentage used } \\
\cline { 2 - 5 } & daily & weekly & monthly & $\begin{array}{c}\text { over } \\
\text { monthly }\end{array}$ & $\begin{array}{c}\text { not } \\
\text { used }\end{array}$ \\
\hline $\begin{array}{l}\text { Use a computer for writing documents (e.g. using } \\
\text { Word) }\end{array}$ & 31.4 & 56.6 & 7.9 & 3.6 & 0.5 \\
\hline $\begin{array}{l}\text { Use a computer to create graphics or manipulate } \\
\text { digital images (e.g. using Photoshop, Flash) }\end{array}$ & 6.7 & 22.5 & 24.4 & 30.4 & 16.0 \\
\hline $\begin{array}{l}\text { Use a computer for creating web pages (e.g. using } \\
\text { Dreamweaver, Frontpage) }\end{array}$ & 3.1 & 4.5 & 5.3 & 36.8 & 50.3 \\
\hline $\begin{array}{l}\text { Use a computer for creating multimedia } \\
\text { presentations (e.g. PowerPoint, Director) }\end{array}$ & 3.4 & 13.4 & 23.4 & 48.6 & 11.1 \\
\hline $\begin{array}{l}\text { Use a computer for creating editing audio and } \\
\text { video (e.g. iMovie) }\end{array}$ & 3.7 & 6.8 & 7.8 & 29.0 & 52.7 \\
\hline $\begin{array}{l}\text { Use a computer for general study, without } \\
\text { accessing the web }\end{array}$ & 24.5 & 37.0 & 12.8 & 15.1 & 10.6 \\
\hline $\begin{array}{l}\text { Use a computer to play digital music files (e.g. } \\
\text { iTunes) without accessing the Internet }\end{array}$ & 57.7 & 26.3 & 3.7 & 4.4 & 7.9 \\
\hline $\begin{array}{l}\text { Use a computer to play games, without accessing } \\
\text { the Internet / web }\end{array}$ & 19.9 & 26.5 & 14.1 & 20.1 & 19.5 \\
\hline Use a games console to play games & 9.4 & 16.2 & 11.9 & 23.9 & 38.5 \\
\hline $\begin{array}{l}\text { Use a handheld computer (e.g. a PDA) as a } \\
\text { personal organiser (e.g. diary, address book) }\end{array}$ & 6.2 & 6.3 & 2.7 & 14.4 & 70.4 \\
\hline
\end{tabular}

Table 3 shows that the majority of students are relying heavily on their mobile phones to call and text people, with $80 \%$ of students texting daily. The newer features of mobile phones - their organising features and taking and sending pictures - are clearly used frequently by a substantial subset of the sample, and are not used at all by a similar but smaller subset. For example, $57.2 \%$ of students are using their mobile phone to take pictures daily or weekly while $30.1 \%$ of students have not used their phone for this activity. Some functions and features of mobile phones are yet to enjoy a wide user base. For example, the vast majority of students have not used their mobile to access web based information and services $(67.8 \%)$ or to send and receive email $(75.8 \%)$.

Table 3: Percentages showing how often students use mobile phone based technologies

\begin{tabular}{|l|c|c|c|c|c|}
\hline \multirow{2}{*}{ Mobile } & \multicolumn{5}{c|}{ Percentage used } \\
\cline { 2 - 6 } & daily & weekly & monthly & $\begin{array}{c}\text { over } \\
\text { monthly }\end{array}$ & not used \\
\hline Use a mobile phone to call people & 76.2 & 16.1 & 2.7 & 1.6 & 3.4 \\
\hline Use a mobile phone to text/ SMS people & 79.5 & 13.2 & 1.8 & 1.3 & 4.1 \\
\hline $\begin{array}{l}\text { Use a mobile phone to take digital photos or } \\
\text { movies }\end{array}$ & 32.2 & 25.0 & 7.7 & 4.9 & 30.1 \\
\hline $\begin{array}{l}\text { Use a mobile phone to send pictures or } \\
\text { movies to other people }\end{array}$ & 18.0 & 14.9 & 11.2 & 8.7 & 47.2 \\
\hline $\begin{array}{l}\text { Use a mobile phone as a personal organiser } \\
\text { (e.g. diary, address book) }\end{array}$ & 29.8 & 21.6 & 6.1 & 6.1 & 36.5 \\
\hline $\begin{array}{l}\text { Use a mobile phone to access information/ } \\
\text { services on the web }\end{array}$ & 8.1 & 9.5 & 4.9 & 9.6 & 67.8 \\
\hline Use a mobile phone to send or receive email & 7.4 & 5.9 & 2.8 & 8.1 & 75.8 \\
\hline
\end{tabular}

A number of instructive results can be seen with regards to incoming first year students' use of web based technologies and tools (see Table 4): 
Table 4: Percentages showing how often students use web based technologies

\begin{tabular}{|c|c|c|c|c|c|}
\hline \multirow[b]{2}{*}{ Web } & \multicolumn{5}{|c|}{ Percentage used } \\
\hline & daily & weekly & monthly & $\begin{array}{c}\text { over } \\
\text { monthly }\end{array}$ & $\begin{array}{l}\text { not } \\
\text { used }\end{array}$ \\
\hline $\begin{array}{l}\text { Use the web to access a school portal, 'Course or } \\
\text { Learning Management System' }\end{array}$ & 26.9 & 36.7 & 7.2 & 7.3 & 21.8 \\
\hline $\begin{array}{l}\text { Use the web to look up reference information for } \\
\text { study purposes (e.g. online dictionaries) }\end{array}$ & 29.7 & 45.9 & 11.2 & 6.9 & 6.3 \\
\hline $\begin{array}{l}\text { Use the web to browse for general information } \\
\text { (e.g. news, holidaying, event timetables) }\end{array}$ & 42.0 & 41.2 & 8.2 & 4.8 & 3.7 \\
\hline $\begin{array}{l}\text { Use the Internet/web or a LAN to play networked } \\
\text { games }\end{array}$ & 11.9 & 12.1 & 8.0 & 17.9 & 50.2 \\
\hline $\begin{array}{l}\text { Use the web to listen to sound recordings (e.g. via } \\
\text { streaming audio or iTunes) }\end{array}$ & 21.5 & 26.6 & 12.0 & 10.8 & 29.1 \\
\hline $\begin{array}{l}\text { Use the web for other pastimes (i.e. for leisure } \\
\text { activities) }\end{array}$ & 37.1 & 35.3 & 7.6 & 5.9 & 14.1 \\
\hline $\begin{array}{l}\text { Use the web to buy or sell things (e.g. eBay, } \\
\text { Amazon, air tickets.) }\end{array}$ & 5.5 & 9.2 & 12.5 & 24.3 & 48.5 \\
\hline $\begin{array}{l}\text { Use the web for other services (e.g. banking, } \\
\text { paying bills) }\end{array}$ & 8.0 & 20.8 & 14.2 & 16.6 & 40.4 \\
\hline $\begin{array}{l}\text { Use the web to send or receive email (e.g. Hotmail, } \\
\text { Yahoo, Outlook) }\end{array}$ & 66.4 & 27.2 & 2.5 & 1.3 & 2.7 \\
\hline $\begin{array}{l}\text { Use the web for instant messaging/ chat (e.g. } \\
M S N, \text { Yahoo, ICQ) }\end{array}$ & 54.7 & 25.1 & 4.5 & 5.3 & 10.4 \\
\hline Use the web to build and maintain a website & 5.3 & 7.5 & 3.8 & 13.6 & 69.7 \\
\hline $\begin{array}{l}\text { Use social networking software on the web (e.g. } \\
\text { MySpace, Trendster) }\end{array}$ & 11.1 & 12.7 & 5.0 & 8.2 & 62.9 \\
\hline $\begin{array}{l}\text { Use the web to download MP3 files (e.g. music, } \\
\text { videos, podcasts) }\end{array}$ & 26.7 & 31.7 & 11.7 & 6.9 & 23.0 \\
\hline $\begin{array}{l}\text { Use the web to upload and share MP3 files (e.g. } \\
\text { music, videos, podcasts) }\end{array}$ & 18.3 & 19.8 & 9.1 & 8.0 & 44.8 \\
\hline $\begin{array}{l}\text { Use the web to share photographs or other digital } \\
\text { material (e.g. using Blinklist, Flickr) }\end{array}$ & 11.9 & 18.8 & 9.6 & 10.1 & 49.5 \\
\hline $\begin{array}{l}\text { Use the web to make phone calls (e.g. VoIP using } \\
\text { Skype) }\end{array}$ & 8.7 & 10.5 & 4.9 & 9.7 & 66.3 \\
\hline $\begin{array}{l}\text { Use the web for web conferencing (e.g. using a } \\
\text { webcam) }\end{array}$ & 8.1 & 10.4 & 6.0 & 9.3 & 66.2 \\
\hline Use the web to read RSS feeds (e.g. news feeds) & 6.5 & 7.4 & 3.6 & 7.3 & 75.1 \\
\hline Use the web to read other people's blogs or vlogs & 15.6 & 22.1 & 10.5 & 10.5 & 41.4 \\
\hline $\begin{array}{l}\text { Use the web to comment on other people's blogs } \\
\text { or vlogs }\end{array}$ & 11.1 & 15.8 & 7.5 & 9.5 & 56.1 \\
\hline Use the web to keep your own blog or vlog & 10.2 & 11.0 & 5.5 & 8.2 & 65.1 \\
\hline $\begin{array}{l}\text { Use the web to contribute to the development of a } \\
\text { wiki }\end{array}$ & 3.3 & 5.2 & 2.3 & 7.6 & 81.6 \\
\hline
\end{tabular}

- Many students $(63.6 \%)$ indicated that they had accessed a learning management system on a daily or weekly basis, but a considerable proportion $(21.8 \%)$ had not used a learning management system in the last year.

- The majority of students (over 85\%) have used the web for study purposes, to gather general information, as a pastime, to send and receive email, and for instant messaging. While there is some variation in the frequency with which students engage in these activities, the vast majority are using the web for these purposes regularly (i.e. daily or weekly). Instant messaging is clearly a popular alternative to email as a web based communication tool. 
- While social networking software such as MySpace has recently grabbed headlines in the media, only $23.8 \%$ of incoming students are engaging in social networking daily or weekly; while $62.9 \%$ of students have never logged on.

- A total of $69.7 \%$ of students have not built and maintained a website in the last year.

- Downloading MP3 music files and podcasts, and sharing these files is clearly an activity enjoyed regularly by a large proportion of students (58.4\% downloading MP3s daily or weekly). Sharing is less common than downloading MP3s and there is a significant proportion of students not engaging in this activity.

- With regards to the more novel communications technologies such as Voice Over IP and web conferencing, a third of students have used them to some extent and two-thirds have never used them.

- RSS feeds seem to be in the startup phase with three quarters of students having not used them.

- A significant blog culture is evident among incoming first year students, given $34.9 \%$ indicated they have kept their own blog in the last year and more are reading $(58.6 \%)$ and commenting on (43.9\%) other people's blogs. A substantial proportion of students (21.2\%) indicated that they were contributing to their own blog on a weekly basis.

- Wikis on the other hand, are less frequently used by students with $81.6 \%$ indicating they had not contributed to this type of web publishing tool before.

The results presented in Tables 2, 3 and 4 show that many of the incoming first year university students surveyed in this study are 'tech-savvy' and are incorporating a range of traditional and emerging technologies in their daily lives. However, there are clearly areas where the use of and familiarity with technology based tools is far from universal or uniform among first year students. Many technology based tools (27 of the 39) were not used by a substantial proportion of students (over 20\%). Moreover, for a number of activities, the proportion of students who have never used a particular technology based tool outstripped those who had (e.g. create a website, keep a blog, web conference, use social networking software, use RSS feeds, use a mobile phone to access the web).

\section{Using technology to assist with university studies}

The final question in the survey presented students with a list of technology based tools that might be used in their university studies. Students were asked to use a rating scale (from 'Strongly Agree' to 'Strongly Disagree') to indicate the extent to which they wanted to use these tools to assist with their university studies. Table 5 presents data for a restricted set of items and the rating scales have been collapsed for ease of interpretation.

Three general categories of responses can be seen for this question. The first includes technologies and tools for which there is very strong support. That is, the vast majority of students (over 75\%) want to use them and very few students (under 5\%) don't want to use them to assist with their university studies. The technologies and tools in this category include using a computer to create digital documents and multimedia presentations, accessing a learning portal, using the web to search for information, using instant messaging and chat, using the web to access university based services, and using SMS. The second category includes tools and technologies for which there is strong but not overwhelming support (45-60\% agree, 11-17\% disagree) and includes being able to download MP3s to assist with their studies (60.6\%), use a mobile phone 
as a personal organiser $(59.8 \%)$, use a mobile phone to access web based information or services $(45.5 \%)$ and use a mobile phone to send or receive email $(45.5 \%)$. The final category of responses reflects technologies and tools for which there is no clear preference either for or against their use (although they always follow a pattern where 'neutral' is greater than 'agree' which is greater than 'disagree'). Technologies and tools that fall into this category include creating a web page or web site, using a PDA, social networking software, web conferencing, RSS feeds and blogs.

Table 5: Percentages of students who do or do not want to use technology based tools to assist with their studies

\begin{tabular}{|c|c|c|c|}
\hline \multirow{2}{*}{$\begin{array}{l}\text { To assist me with my University studies } \\
\text { I want to be able to use... }\end{array}$} & \multicolumn{3}{|c|}{ Percent } \\
\hline & Agree & Neutral & Disagree \\
\hline A computer for general study & 93.8 & 5.2 & 1.0 \\
\hline A computer to create documents (e.g. using Word, Excel, PDFs) & 94.6 & 4.4 & 1.0 \\
\hline A computer to create web pages (e.g. using Dreamweaver, Frontpage) & 37.8 & 43.0 & 19.1 \\
\hline $\begin{array}{l}\text { A computer to create multimedia presentations (e.g. PowerPoint, } \\
\text { Director) }\end{array}$ & 75.4 & 19.9 & 4.7 \\
\hline $\begin{array}{l}\text { A handheld computer (e.g. a PDA) as a personal organiser (e.g. } \\
\text { diary, address book) }\end{array}$ & 37.1 & 39.9 & 23.0 \\
\hline $\begin{array}{l}\text { The web to access a learning portal (e.g. a 'Course' or 'Learning } \\
\text { Management System') }\end{array}$ & 80.9 & 14.9 & 4.1 \\
\hline $\begin{array}{l}\text { The web to look up or search for information (e.g. online } \\
\text { dictionaries, Google) }\end{array}$ & 93.4 & 5.2 & 1.4 \\
\hline $\begin{array}{l}\text { The web for other services (e.g. enrolment, sign up for tutes, paying } \\
\text { fees) }\end{array}$ & 83.9 & 12.0 & 4.0 \\
\hline The web for instant messaging/ chat (e.g. MSN, Yahoo, ICQ) & 74.6 & 18.7 & 6.7 \\
\hline The web to build and maintain a website & 33.0 & 43.5 & 23.5 \\
\hline Social networking software on the web (e.g. MySpace, Trendster) & 31.8 & 44.5 & 23.7 \\
\hline The web to download MP3 files (e.g. podcasts, iTunes) & 60.6 & 28.0 & 11.4 \\
\hline The web for web conferencing (e.g. using a webcam) & 38.5 & 40.8 & 20.7 \\
\hline The web to read RSS feeds (e.g. news feeds) & 32.6 & 47.4 & 20.0 \\
\hline The web to keep my own blog or vlog & 32.2 & 42.4 & 25.4 \\
\hline A mobile phone to send or receive text messages/ SMSs & 84.2 & 11.6 & 4.3 \\
\hline A mobile phone as a personal organiser (e.g. diary, address book) & 59.8 & 30.1 & 10.1 \\
\hline A mobile phone to access web based information or services & 45.5 & 39.0 & 15.5 \\
\hline A mobile phone to send or receive email & 45.5 & 38.0 & 16.5 \\
\hline
\end{tabular}

The final set of analyses considered the degree to which students' attitudes towards the use of emerging technology based tools in their studies was related to the frequency with which they currently used these tools. Seven emerging technologies based tools or activities were included in this analysis: keeping a blog, downloading MP3s, texting on mobile phones, using instant messaging, using RSS feeds, contributing to a wiki, and using social networking software on the web. A series of chi-square analyses were used to determine the association between the degree to which students used a technology based tool and the degree to which they endorsed its use in their studies at University. Six of the seven chi-square tests showed a significant pattern of association that is exemplified by the item Keeping a blog $\left(\chi^{2}(6)=\right.$ 78.01; $\mathrm{p}<.001$ ) (see Table 6). This table shows a strong relationship between the frequency with which blogs are used and the desire for their use at university. This is reflected in the over-representation of respondents in the 'daily' use by 'agree' category, and the 'over monthly' use and 'disagree' category (and conversely, an under-representation in the 'daily' /'disagree' and 'over monthly'/'agree' categories). 
This general pattern of results was also seen for instant messaging, social networking, texting, RSS feeds and downloading MP3s.

Table 6: Observed counts and standardised residuals for a chi-square test of association between Current use and Desire for use for the item Keeping a blog.

\begin{tabular}{|c|c|c|c|c|}
\hline \multirow{2}{*}{ Keeping a blog } & \multicolumn{3}{|c|}{ Desire for use } \\
\cline { 3 - 5 } \multicolumn{2}{|c|}{$\begin{array}{c}\text { Yes } \\
\text { Obs (Std Res) }\end{array}$} & $\begin{array}{c}\text { Neutral } \\
\text { Obs (Std Res) }\end{array}$ & $\begin{array}{c}\text { No } \\
\text { Obs (Std Res) }\end{array}$ \\
\hline \multirow{3}{*}{$\begin{array}{l}\text { Current } \\
\text { use }\end{array}$} & Daily & $145\left(3.9^{*}\right)$ & $28\left(-4.0^{*}\right)$ & $7\left(-2.4^{*}\right)$ \\
\cline { 2 - 5 } & Weekly & $114(.0)$ & $65(.1)$ & $17(-.3)$ \\
\cline { 2 - 5 } & Monthly & $50(-.7)$ & $36(.9)$ & $9(.1)$ \\
\cline { 2 - 5 } & Over monthly & $42\left(-4.0^{*}\right)$ & $68\left(3.7^{*}\right)$ & $23\left(3.0^{*}\right)$ \\
\hline
\end{tabular}

${ }^{*} \mathrm{p}<.05$

\section{Discussion}

This study of first year university students' access to, and uses and perceptions of a range of technologies has significant implications for the Australian higher education sector. At a time of growing interest in the attributes of the so-called Digital Natives, it is important for Australian universities to ensure that decision making about how to enhance the learning experiences of incoming university students through the use of technology is both evidence based and empirically informed.

The results of this study highlight the lack of homogeneity in the incoming first year student population with regards to technology and a potential 'digital divide' between students within a cohort of a single year level. While some students have embraced the technologies and tools of the 'Net Generation', this is by no means the universal student experience. When one moves beyond entrenched technologies and tools (e.g. computers, mobile phones, email), the patterns of access to, use of and preference for a range of other technologies show considerable variation. These findings run counter to key assumptions underpinning Prensky's (2001a) construct of the Digital Natives. Given this, the widespread revision of curricula to accommodate the so-called Digital Natives does not seem warranted and, moreover, it would be difficult to start "Adapting materials to the language of Digital Natives" (Prensky, 2001a; p. 4) when they so obviously speak with a variety of tongues.

As suggested in the introduction to this paper, the level of technological diversity revealed in this paper is starting to be acknowledged by educational technology researchers. It is increasingly recognised that while the majority of incoming university students possess a core set of technology based skills, beyond those a diverse range of skills exist across the student population (see Caruso \& Kvavik, 2005). Moreover, it is recognised that core technology based skills do not necessarily translate into sophisticated skills with other technologies or general information literacy. Kirkwood and Price (2005) argue that "few students have high levels of competence across a wide range of applications" and that "familiarity with the use of email does not imply expertise in rigorous online debate and discussion" (p. 271). Similarly Lorenzo, Oblinger and Dziubam (2006) state: “Today's students are not just the traditional-age Net Generation, nor have they all had the benefit of state-of-the-art, ubiquitous technology. Higher education comprises a highly diverse and growing student body with a wide variety of information literacy capabilities." (p. 4). Clearly we cannot 
assume that being a member of the 'Net Generation' is synonymous with knowing how to employ technology based tools strategically to optimise learning experiences in university settings.

Given this diversity within a single cohort of first year students, the challenge for educators and university administrators is how to cater for the broad range in students' levels of access to, familiarity with, and preference for different technologies and technology based tools. This study clearly provides sufficient evidence to negate the 'one size fits all' approach to the integration of ICTs into university curricula. While there are few easy answers in this area, the rather tired but true mantra that any technological integration should be pedagogically driven still holds. Educators and educational developers with expertise in both existing and emerging technologies need to be proactive in this respect. Against the backdrop of this principle, educators and administrators should look to the evidence about what technologies students have access to and what their preferences are. Rather than making assumptions about what students like - and are like - universities and their staff must look to the evidence to inform both policy and practice.

An important consideration in this discussion is student equity. Take, for example, the area of podcasting. The use of podcasts in education settings is rapidly gaining acceptance (e.g. Lee, Chan \& McLoughlin, 2006; Maag, 2006; McLoughlin, Lee \& Chan, 2006) and while data from this study revealed a majority of students want to be able to download MP3s to assist with their studies, almost $40 \%$ of students are uncertain about or do not wish to use this form of technology in their learning. Moreover, 23\% of students have never used the web to download MP3 files and, at the time of the study, $14 \%$ relied on dialup Internet access which would have rendered large MP3 files prohibitively slow to download. While a recent study by Lee, Chan and McLoughlin (2006) suggested that many students preferred to listen to podcast learning material at their computers, the often cited advantage of MP3s is that learners can access them anytime, anywhere via portable MP3 players. However, one in five students in this study reported no access to dedicated MP3 players (although many mobile phones now have this capability). While these figures in no way suggest a moratorium on the use of podcasting, they do indicate the need to provide appropriate support for students.

Notwithstanding the overall message of diversity among students, there are a selection of tools and technologies for which use and access border on being both universal and uniform. Students are relying heavily on computers for study and for listening to music; almost all have mobile phones for calling and texting others; they regularly use the Internet for information gathering, email and instant messaging. In addition, the vast majority want to use the web to search for information for their university studies, to access university services and to use a portal as a gateway to learning material. These results are supported by previous research (Caruso \& Kvavik, 2005; Jones, 2002) and when combined these findings show that today's students are relying on mainstream technologies (computers, mobile phones, and the Internet) for fast communication, and convenient access to information and services. While we cannot expect that all students will be adept with an array of new and emerging technologies, they may increasingly bring to university general expectations about access, convenience and connectedness (see Caruso and Kvavik's (2005) ECAR framework). This may have particular implications for the administrative services provided by universities (both general student services and teaching and learning services). 
Moreover, despite the diversity of technological experience in this sample of first year students, the degree to which they are using of some emerging technologies and tools does point to a number of promising opportunities for integrating innovative technologies into university curricula. It cannot be ignored that substantial proportions of incoming university students are using and reading blogs, are taking photos with their mobile phones, are regularly using social networking software such as MySpace, are communicating via web conferencing, and are sharing all sorts of digital files using both their mobile phones and the web. The potential for harnessing these technologies and activities for educational purposes is being actively discussed and effectively realised (e.g. Downes, 2004; New Media Consortium, 2006, Instone, 2005; West, Wright, Gabbitas \& Graham, 2006; Williams \& Jacobs, 2004; Bryant, 2006).

The final set of analyses in this study assessed the question of whether students who use a particular technology in their everyday lives also want to use it in their studies. The data reported in this paper indicate that for a range of emerging technologies (blogs, instant messaging, texting, social networking, RSS feeds and downloading MP3s) the answer seems to be 'Yes'. However, limitations in the design of this component of the investigation leave the observed association open to a variety of explanations. For example, it may be that 'early adopters' who have keenly embraced technologies for non-educational purposes may also be likely to perceive these same technologies as having wider education value. Conversely, some students may not have had enough experience with a technology to envisage how it could be usefully applied. Also it is difficult to expect students to have the expertise to judge how to best use emerging technologies for educational purposes.

An obvious difficulty associated with interpreting this finding is that we did not ask students about how they thought technologies could be used in educational settings. For example, the technology most widely accessed by this cohort is the mobile phone (96\% have one) and more than 90 percent use it to 'text' on a weekly basis. Perhaps not surprisingly then, when asked to nominate technologies that might assist with their studies, the majority of students $(84 \%)$ agreed that they would like to send or receive text messages via their mobile phone. While there was strong endorsement for using text messaging as part of university studies, we did not canvass ways in which SMS might be used in an educational setting, either by suggesting uses to students or asking them to suggest uses. Students may have particular ideas about how their mobile phones could be used to support their learning (e.g. texting marks or cancelled classes), and these may well be different from University staff (e.g. texting pre-tutorial questions).

More research is needed to determine the specific circumstances under which students would like their 'living technologies' to be adapted as 'learning technologies'. The positive association between students' use of technology and their preference for its use at University leaves unanswered the question as to whether students' everyday skills with emerging technologies will correspond to skills associated with beneficial, technology based learning. As noted by a number of authors (Kirkwood \& Price, 2005; Katz, 2005) the transfer from a social or entertainment technology (a living technology) to a learning technology is neither automatic nor guaranteed. These issues point to many unresolved issues that warrant further investigation. 


\section{Conclusions and future directions}

For this ongoing research project the underlying issue - and the challenge - remains a familiar one. As university educators we must be attuned to the ever changing and often diverse characteristics of our student cohorts. Evidence of who our students are must remain an important factor in informing how we use the array of technological tools at our disposal to design rich and engaging learning experiences for all students. There are numerous examples of how educators and educational developers have done this well, with many different types of technology, over very many years.

The investigation reported in this paper would have benefited from more in depth, qualitative investigation of both students' and teachers' perspectives on technology from a broader range of universities which reflect the diversity of Australian higher education. A larger investigation that has recently been supported by the Carrick Institute for Learning and Teaching in Higher Education (see Kennedy, Krause, Gray, Judd, Bennett, Maton, Dalgarno \& Bishop, 2006; Kennedy, Dalgarno, Gray, Judd, Waycott, Bennett, Maton, Krause, Bishop, Chang, \& Churchward, 2007) will continue this program of research and will consider staff and student perspectives across a diverse range of Australian universities.

\section{Acknowledgements}

This research would not have been possible without the cooperation of staff and students from The University of Melbourne. The research reported in this paper was sponsored by the Pro Vice-Chancellor (Teaching, Learning and Equity) at The University of Melbourne, Associate Professor Susan Elliott. We would particularly like to acknowledge our discussions with Dr Barney Dalgarno and Dr Sue Bennett, which usefully informed the preparation of this paper.

\section{References}

Australian Psychological Society (2004). Psychosocial aspects of mobile phone use among adolescents. Australian Psychological Society.

Bryant, T. (2006). Social software in academia. EDUCAUSE Quarterly, 29(2), 61-64. http: / / connect.educause.edu/Library / EDUCAUSE+Quarterly/SocialSoftwareinAcademia/39976

Caruso, J. B. \& Kvavik, R. (2005). ECAR study of students and information technology 2005: Convenience, connection, control, and learning. EDUCAUSE. http: / / connect.educause.edu/Library / ECAR/ECARStudyofStudentsandInf/ 41159

Doherty, L. (2005). Where worlds collide and pupils leave teachers behind. Sydney Morning Herald, October 1, 2005.

Downes, S. (2004). Educational blogging. EDUCAUSE Review, 39(5), 14-26. http: / / connect.educause.edu/Library / EDUCAUSE+Review / EducationalBlogging / 40493

Frand, J. L. (2000). The information-age mindset. Changes in students and implications for higher education. EDUCAUSE Review, 35(5), 15-24.

http:/ / www.educause.edu/ir/library/pdf/ERM0051.pdf

Gibbons, S. (2007). Redefining the roles of information professionals in higher education to engage the Net generation. Keynote Paper presented at Educause Australasia 2007. [viewed 23 Jul 2007]. http:/ / www.caudit.edu.au/educauseaustralasia07/authors_papers/Gibbons2.pdf 
Gros, B. (2003). The impact of digital games in education. First Monday, 8(7). http:/ / www.firstmonday.org/issues/issue8_7/xyzgros/index.html

Instone, L. (2005). Conversations beyond the classroom: Blogging in a professional development course. In Balance, Fidelity, Mobility: Maintaining the momentum? Proceedings ASCILITE 2005. http:/ / www.ascilite.org.au/conferences/brisbane05/blogs/proceedings/34_Instone.pdf

Jones, S. \& Madden, M. (2002). The Internet goes to college: How students are living in the future with today's technology. Washington DC: Pew Internet \& American Life Project. [viewed 7 Apr 2007, verified 18 Jan 2008] http: / / www.pewinternet.org/pdfs/PIP_College_Report.pdf

Katz, R. (2005). Foreword: Growing up digital. In J. B. Caruso \& R. Kvavik (Eds), ECAR study of students and information technology, 2005: Convenience, connection, control, and learning. EDUCAUSE. http: / / connect.educause.edu/Library/ECAR/ECARStudyofStudentsandInf/ 41159

Kennedy, G., Krause, K., Gray, K., Judd, T., Bennett, S., Maton, K., Dalgarno, B. \& Bishop, A. (2006). Questioning the Net generation: A collaborative project in Australian higher education. In Who's learning? Whose technology? Proceedings ASCILITE 2006 (pp. 413-417). Sydney: Sydney University Press. http: / / www.ascilite.org.au/conferences / sydney06/proceeding/pdf_papers/p160.pdf

Kennedy, G., Dalgarno, B., Gray, K., Judd, T., Waycott, J., Bennett, S., Maton, K., Krause, K., Bishop, A., Chang, R. \& Churchward, A. (2007). The net generation are not big users of Web 2.0 technologies: Preliminary findings from a large cross-institutional study. In Providing choices for learners and learning. Proceedings ascilite Singapore 2007 (pp. 517-525). Singapore: Nanyang Technological University. http: / / www.ascilite.org.au/conferences/ singapore07/ procs/ kennedy.pdf

Kirkwood, A. \& Price, L. (2005). Learners and learning in the 21st century: What do we know about students' attitudes and experiences of ICT that will help us design courses? Studies in Higher Education, 30(3), 257-274.

Krause, K., Hartley, R., James, R. \& McInnes, C. (2005). The first year experience in Australian universities: Findings from a decade of national studies. Department of Education, Science and Training. Canberra, Australia. http:/ / www.dest.gov.au/sectors/higher_education/ publications_resources/profiles/first_year_experience.htm

Kvavik, R.B. (2005). Convenience, communications, and control: How students use technology. In D. Oblinger \& J. Oblinger (Eds.), Educating the Net Generation (pp. 7.1-7.20). EDUCAUSE. http: / / www.educause.edu/educatingthenetgen/

Lee, M., Chan, A. \& McLoughlin, C. (2006). Educational podcasting using the Charles Sturt University flexible publishing platform. Proceedings E-Learn 2006. http: / / csusap.csu.edu.au/ achan/ papers / 2006_POD_ELEARN.pdf

Lorenzo, G., Oblinger, D. \& Dziuban, C. (2006). How choice, co-creation, and culture are changing what it means to be net savvy. EDUCAUSE Quarterly, 30(1). http:// connect.educause.edu/Library/EDUCAUSE+Quarterly/HowChoiceCoCreationandCul/ 40008

Maag, M. (2006). iPod, uPod? An emerging mobile learning tool in nursing education and students' satisfaction. In Who's learning? Whose technology? Proceedings ASCILITE 2006 (pp. 483-492). Sydney: Sydney University Press. http: / / www.ascilite.org.au/conferences / sydney06/ proceeding/pdf_papers / p92.pdf

McLoughlin, C., Lee, M. J. W. \& Chan, A. (2006). Using student generated podcasts to foster reflection and metacognition. Australian Educational Computing, 21(2), 34-40. [verified 18 Jan 2008] http: / / www.acce.edu.au / JournalDB / GetIssuePDF.asp?IssueID=81

NetRatings (2005). Kidsonline@home. Internet use in Australian homes. NetRatings Australia Pty Ltd. [verified 18 Jan 2008] http:/ / www.acma.gov.au/webwr/aba/about/recruitment/kidsonline.pdf

New Media Consortium (2006). The Horizon Report 2006. NMC and EDUCAUSE. http:// www.nmc.org/pdf/2006_Horizon_Report.pdf 
Oblinger, D. (2003). Boomers, Gen-Xers \& Millennials. Understanding the new students. EDUCAUSE Review, 38(4), 37-47. http:/ / www.educause.edu/ir/library/pdf/ERM0342.pdf

Oblinger, D. (2006). Listening to what we're seeing. Keynote Paper presented at ALT-C 2006. http:/ / www.alt.ac.uk/docs/Diana_Oblinger_20060905_25MB_88Mins.mp3 [viewed 23 July 2007].

Oliver, B. \& Goerke, V. (2007). Australian undergraduates' use and ownership of emerging technologies: Implications and opportunities for creating engaging learning experiences for the Net Generation. Australasian Journal of Educational Technology, 23(2), 171-186. http:/ / www.ascilite.org.au/ajet/ajet23/oliver.html

Prenksy, M. (2001a). Digital Natives, Digital Immigrants. On the Horizon, 9(5). http: / / www.marcprensky.com/ writing/Prensky\%20\%20Digital\%20Natives, \%20Digital\%20Immigrants\%20-\%20Part1.pdf

Prenksy, M. (2001b). Digital Natives, Digital Immigrants, Part II. Do they really think differently? On the Horizon, 9(6). http: / / www.marcprensky.com/ writing/Prensky\%20$\%$ 20Digital\%20Natives,\%20Digital\%20Immigrants\%20-\%20Part2.pdf

Prensky, M. (2007). How to teach with technology: Keeping both teachers and students comfortable in an era of exponential change. Emerging Technologies for Learning, Vol. 2 (2007). [viewed 23 July 2007]. http:/ / partners.becta.org.uk/ page_documents/research/ emerging_technologies07_chapter4.pdf

Rodley, C. (2005). Meeting the demands of the Net Gen. UniNews, The University of Sydney, 28 October 2005. [verified 18 Jan 2008]. http:/ / www.usyd.edu.au/news/84.html?newsstoryid=744

West, R. E., Wright, G., Gabbitas, B. \& Graham, C. R. (2006). Reflections from the introduction of blogs and RSS feeds into a preservice instructional technology course. TechTrends, 50(4), 5460 .

Williams, J. B. \& Jacobs, J. (2004). Exploring the use of blogs as learning spaces in the higher education sector. Australasian Journal of Educational Technology, 20(2), 232-247. http:/ / www.ascilite.org.au/ajet/ajet20/ williams.html

Gregor E. Kennedy, Terry S. Judd, Anna Churchward, Kathleen Gray

Biomedical Multimedia Unit, Faculty of Medicine, Dentistry and Health Sciences The University of Melbourne, 766 Elizabeth Street, Parkville VIC 3010, Australia

Kerri-Lee Krause, Griffith Institute for Higher Education, Griffith University, 170 Kessels Road, Nathan QLD 4111, Australia

Corresponding Author:

Dr Gregor Kennedy, Biomedical Multimedia Unit

Faculty of Medicine, Dentistry and Health Sciences

The University of Melbourne, 766 Elizabeth Street

Parkville VIC 3010, Australia

Email: gek@unimelb.edu.au 